\title{
Corrosion Inhibition of Tin in Sodium Chloride Solutions Using Propaneitrile Derivatives
}

\author{
A.S. FOUDA ${ }^{* 1}$, S.A. ABDEL-MAKSOUD ${ }^{2}$ and A.E. ALMETWALLY ${ }^{1}$ \\ ${ }^{1}$ Chemistry Department, Faculty of Science, El-Mansoura University, \\ El-Mansoura-35516, Egypt \\ ${ }^{2}$ Chemistry Department, Faculty of Science, Port Said University, Port Said, Egypt \\ asfouda@mans.edu.eg
}

Received 14 October 2014 / Accepted 8 November 2014

\begin{abstract}
Inhibition of corrosion of tin in $0.6 \mathrm{M} \mathrm{NaCl}$ by some propaneitrile derivatives namely: $(2 E)$ 3-(1H-indol-3-yl)-3-oxo-2-(3.4-diphenyl thiazol-2(3H)-ylidene)propanenitrile, (E)-3-(1H - indol-3yl) -3-oxo-2- (5-oxo-3-phenyl thiazolidin-2-ylidene) propanenitrile, (E)-3-(1H-indol-3-yl)-3-yl)-3-oxo2-(5-oxo-3-phenyl thiazolidin-2-ylidene) propanenitrile and (2-imino- $2 H$-chromen-3-yl)(1H-indol-3yl) methadone as investigated by potentiodynamic polarization, electrochemical impedance spectroscopy (EIS) and electrochemical frequency modulation (EFM) techniques. Polarization studies were carried out at different temperatures and showed that the investigated compounds were mixed type inhibitors. The effect of temperature on corrosion inhibition has been studied and some thermodynamic activation and adsorption parameters were calculated and discussed. The inhibition occurs through adsorption of the investigated compounds on the tin surface without modifying the mechanism of corrosion process. The experimental data fit Freundlich adsorption isotherm.
\end{abstract}

Keywords: Corrosion inhibition, Propanenitrile derivatives, Tin

\section{Introduction}

Corrosion is a fundamental process playing an important role in economy and safety, particularly for metals and alloys. Tin is a moderately corrosion-resistant material widely used in industry in the production of tin cans, soft solders, bronze, and dental amalgam ${ }^{1}$. This metal is very suitable in many important applications, owing to its main properties such as low melting point, malleability, good resistance to corrosion and its non-toxic nature in the food pro-ceasing industry and environmental regulations. It was postulated that the extremely low corrosion rate was due to the presence of a thin, stable passive film that forms on the metal surface ${ }^{2}$. It is very important to add corrosion inhibitors to decrease the corrosion rate of the metals or alloys. The use of inhibitors is the most practical method of protection against corrosion, especially in acidic environments ${ }^{3,4}$. Many organic compounds were tested and industrially applied as corrosion inhibitors, nontoxic are far more strategic now than in the recent past ${ }^{5,6}$. For this reason, most of the electrochemical studies dealing 
with tin surface properties are devoted to the physical properties of these oxide layers. Indeed, tin oxides have been shown to behave as semiconductor materials. Depending on the $\mathrm{pH}$ of the solution and the potential for anodization, the stoichiometric composition of the oxide $^{7}$. It has been commonly recognized that an organic inhibitor usually promotes formation of a chelate on a metal surface by electron transfer from the organic compound to the metal and forming a coordinate covalent bond during the chemical adsorption ${ }^{8}$. The inhibition mechanisms are (i) the inhibitor is adsorbed on the surface of the metal forming a compact protective thin layer and (ii) the inhibitor forms a precipitate on the surface of the metal, acting on the aggressive medium to form protective precipitates or remove aggressive agents. Some inhibitors act on the cathode (cathodic inhibitor) or on the anode (anodic inhibitor) or on both (mixed mechanism inhibitor) ${ }^{9-11}$. The unique advantage of the possibility of adding inhibitors is that the industrial process can be done without disruption. Organic corrosion inhibitors are useful when their addition in small amounts prevents corrosion. At higher concentrations of organic compounds an additional testing for environmental impact is required ${ }^{12-14}$. Most of the well-known acid inhibitors are organic compounds containing nitrogen, sulphur and oxygen atoms ${ }^{15-18}$.

The aim of the present study is to investigate the inhibitive effect of some investigated compounds on the corrosion of tin in $0.6 \mathrm{M} \mathrm{NaCl}$ solution using extrapolation of cathodic and anodic Tafel lines at different temperatures. The mode of adsorption and the corrosion inhibition mechanism are also discussed, as well as the calculated thermodynamic parameters.

\section{Experimental}

A rod of tin $99.99 \%$ Johnson Matthey was used as tin working electrode with an apparent surface area of $1 \mathrm{~cm}^{2}$ was inserted into a Teflon tube so that only the flat surface was in contact with solution. Before each experiment, the electrode was abraded with a sequence of emery papers of different grades $(600,800$ and 1200), washed with double distilled water and degreased with acetone. All chemicals used were of analytical grade reagents. The corrosive solution was $0.6 \mathrm{M} \mathrm{NaCl}$ and prepared using double distilled water. The experiments were carried out under non-stirred and naturally aerated conditions. The inhibitor solutions were prepared at different concentrations using dimethyl formamide (DMF) and ethanol solvents.

\section{Inhibitors}

The selected organic inhibitors used in this study were synthesized through procedures reported previously ${ }^{19}$. The structure formulae of inhibitors are shown Table 1 .

\section{Methods}

\section{Potentiodynamic polarization measurements}

Electrochemical experiments were performed in a conventional three electrode electrochemical cell at $25{ }^{\circ} \mathrm{C}$ with a platinum counter electrode and saturated calomel (SCE) as reference electrode. The working electrode was in the form of disc cut from the alloy under investigation, first was immersed into the test solution for $30 \mathrm{~min}$ to establish a steady state open circuit potential. The potentiodynamic current-potential curves were recorded by changing the electrode potential automatically from $-0.50 \mathrm{mV}$ to $+0.50 \mathrm{mV}$ with scanning rate of $5 \mathrm{mV} \mathrm{s}^{-1}$. Corrosion potential $\left(\mathrm{E}_{\text {corr }}\right)$ and corrosion current densities $\left(\mathrm{j}_{\text {corr }}\right)$ were evaluated from intersection of the linear anodic and cathodic branches of Tafel plots and all of them were calculated in absence and presence of different concentrations of inhibitors. Experiments were always repeated at least three times. Degree of surface coverage $(\theta)$ and inhibition efficiency (\% IE) were calculated using equation $(1)^{20}$. 
Table 1. The names, structures, molecular weights and molecular formulas of the investigated inhibitors

Inhibitor

\section{Electrochemical impedance spectroscopy (EIS) measurements}

The cell and the apparatus used in electrochemical impedance spectroscopy (EIS) is the same as used in potentiodynamic polarization. After the determination of steady-state potential (30 min of exposure), the wave voltage $5 \mathrm{mV}$ peak to peak, at frequencies between $100 \mathrm{kHz}$ and $0.1 \mathrm{~Hz}$ were superimposed on the rest potential. All the potentials reported are referred to SCE. The impedance diagrams are given in the Nyquist and Bode representations. Experiments were always repeated at least three times. Degree of surface coverage $(\theta)$ and $\%$ IE was calculated using the following equations:

$$
\% \mathrm{IE}=\theta \times 100=\left[\left(1 / \mathrm{R}_{\mathrm{ct}}^{\prime}\right)-\left(1 / \mathrm{R}_{\mathrm{ct}}\right)\right] /\left(1 / \mathrm{R}_{\mathrm{ct}}^{\prime}\right)
$$

where $R^{\prime}$ ct and $R_{c t}$ are the charge transfer resistance in the presence and absence of inhibitor, respectively. 


\section{Electrochemical frequency modulation (EFM)}

EFM measurements were performed with applying potential perturbation signal with amplitude of $10 \mathrm{mV}$ with two sine waves of 2 and $5 \mathrm{~Hz}$. The electrochemical studies were performed using Gamry Potentiostat/Galvanostat (Gamry PCI 300/4) with a Gamry framework system based on ESA300. Gamry applications include software DC105 for polarization, EIS300 for EIS and EFM140 for electrochemical frequency modulation measurements and Echem Analyst version 5.5 software packages for data fitting. The working electrode was immersed in the acid solution for $30 \mathrm{~min}$ in order to attain the steadystate (open circuit) potential before the electrochemical tests.

\section{Results and Discussion}

\section{Potentiodynamic polarization measurements}

The potentiodynamic polarization curves for tin in $0.6 \mathrm{M} \mathrm{NaCl}$ solutions containing different concentrations of compound (S11) at $25^{\circ} \mathrm{C}$ are shown in Figure 1. Similar curves were obtained for other compounds.

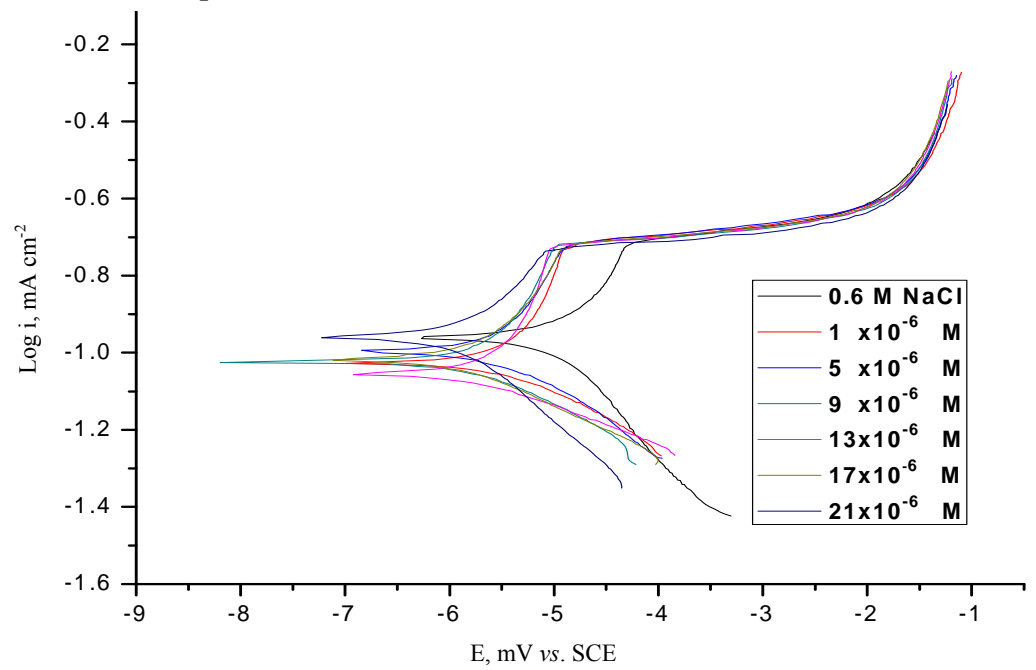

Figure 1. Potentiodynamic polarization curves for tin in $0.6 \mathrm{M} \mathrm{NaCl}$ in the absence and presence of different concentrations of compound (S11) at $25{ }^{\circ} \mathrm{C}$

Potentiodynamic polarization parameter such as corrosion potential $\left(\mathrm{E}_{\mathrm{corr}}\right)$, corrosion current density $\left(i_{\text {corr }}\right)$ cathodic and anodic Tafel slope $\left(\beta_{c}\right.$ and $\left.\beta_{\mathrm{a}}\right)$, degree of surface coverage $(\theta)$, polarization resistance $\left(\mathrm{R}_{\mathrm{p}}\right)$ and percentage inhibition efficiency $(\% \mathrm{IE})$ are summarized in Table 2 for the corrosion of tin in $0.6 \mathrm{M} \mathrm{NaCl}$ in the absence and presence of different concentration of inhibitors. The results show that the corrosion current $\left(\mathrm{i}_{\text {corr }}\right)$ decreases with increasing the inhibitor concentration and hence, the inhibition efficiency increases. The order of inhibition efficiency of investigated compounds is as follows: $\mathrm{S} 11>\mathrm{S} 12>\mathrm{S} 13>$ $\mathrm{S} 14$. A compound can be classified as an anodic-or cathodic-type inhibitor when the change in the $\mathrm{E}_{\text {corr }}$ value is larger than $85 \mathrm{mV}^{21}$. Since the largest displacement exhibited by these inhibitors was $44 \mathrm{mV}$ at $25^{\circ} \mathrm{C}$ (Table 2). It may concluded that these molecules should be considered as a mixed-type inhibitor, meaning that the addition of these inhibitors to $0.6 \mathrm{M}$ $\mathrm{NaCl}$ solution reduces both the anodic dissolution of tin and also to retards the cathodic hydrogen evolution reaction. Adsorption is the mechanism generally accepted to explain the 
inhibitory action of corrosion inhibitors. The adsorption of inhibitors can affect the corrosion rate in two ways: (i) by decreasing the available reaction area, the so called geometric blocking effect and (ii) by modifying the activation energy of the cathodic and/or anodic reactions occurring in the inhibitor-free metal in the course of the inhibited corrosion process. It a difficult task to determine which aspects of the inhibiting effect are connected to the geometric blocking action and which are connected to the energy effect. Theoretically, no shifts in $\mathrm{E}_{\text {corr }}$, should be observed after addition of the corrosion inhibitor if the geometric blocking effect is stronger than the energy effect ${ }^{22}$. No change observed in $\mathrm{E}_{\text {corr }}$ values upon addition of inhibitors indicates that geometric blocking effect is smaller, although the energy effect cannot be ignored.

Table 2. Data from potentiodynamic polarization of tin in $0.6 \mathrm{M} \mathrm{NaCl}$ containing different concentrations of investigated compounds at $25^{\circ} \mathrm{C}$

\begin{tabular}{cccccccc}
\hline \multirow{2}{*}{ Compounds } & $\begin{array}{c}\text { Conc.X } \\
10^{6} \mathrm{M}\end{array}$ & $\begin{array}{c}-\mathrm{E}_{\text {corr }} \\
\mathrm{mV} v \mathrm{~s} . \mathrm{SCE}\end{array}$ & $\begin{array}{c}\mathrm{i}_{\text {corr }} \\
\mu \mathrm{A} \mathrm{cm}\end{array}$ & $\begin{array}{c}\beta_{\mathrm{a}} \\
\mathrm{mVdec}^{-1}\end{array}$ & $\begin{array}{c}\beta_{\mathrm{c}} \\
\mathrm{mVdec}^{-1}\end{array}$ & $\theta$ & $\%$ IE \\
\hline Blank & 0.0 & 0.96 & 13.630 & 348 & 338 & ---- & ---- \\
& 1 & 0.85 & 4.810 & 425 & 105 & 0.647 & 64.7 \\
& 5 & 0.99 & 3.894 & 191 & 500 & 0.714 & 71.4 \\
S11 & 9 & 1.03 & 3.034 & 187 & 546 & 0.777 & 77.7 \\
& 13 & 1.06 & 2.604 & 119 & 525 & 0.809 & 80.9 \\
& 17 & 1.02 & 1.723 & 146 & 304 & 0.874 & 87.4 \\
& 21 & 0.73 & 1.034 & 265 & 280 & 0.880 & 88.0 \\
& 1 & 1.21 & 5.124 & 161 & 737 & 0.624 & 62.4 \\
S12 & 5 & 1.03 & 4.339 & 185 & 111 & 0.682 & 68.2 \\
& 9 & 1.02 & 4.086 & 172 & 579 & 0.700 & 70.0 \\
& 13 & 1.19 & 3.671 & 174 & 644 & 0.731 & 73.1 \\
& 17 & 1.09 & 2.374 & 141 & 454 & 0.826 & 82.6 \\
& 21 & 0.99 & 2.056 & 152 & 300 & 0.849 & 84.9 \\
& 1 & 1.21 & 5.239 & 150 & 879 & 0.616 & 61.6 \\
S13 & 5 & 1.07 & 4.613 & 164 & 731 & 0.662 & 66.2 \\
& 9 & 1.11 & 4.145 & 206 & 725 & 0.696 & 69.6 \\
& 13 & 1.42 & 3.818 & 142 & 669 & 0.720 & 72.0 \\
& 17 & 1.15 & 2.950 & 158 & 618 & 0.784 & 78.4 \\
& 21 & 0.99 & 2.212 & 208 & 319 & 0.838 & 83.8 \\
& 1 & 1.06 & 5.308 & 180 & 790 & 0.610 & 61.0 \\
& 5 & 1.03 & 4.770 & 168 & 638 & 0.650 & 65.0 \\
& 9 & 1.14 & 4.596 & 178 & 750 & 0.663 & 66.3 \\
& 13 & 1.17 & 3.944 & 177 & 824 & 0.711 & 71.1 \\
& 17 & 1.02 & 3.399 & 247 & 547 & 0.751 & 75.1 \\
& 21 & 1.05 & 2.604 & 119.4 & 525.2 & 0.809 & 80.9 \\
\hline \multirow{5}{*}{ S14 } & 13 & & & & & &
\end{tabular}

Electrochemical impedance spectroscopy (EIS) measurements

Electrochemical impedance spectroscopy (EIS), is a powerful technique in studying corrosion mechanisms and adsorption phenomena ${ }^{23}$. This technique enables the simulation of the experimental impedance results to theoretical data according to proposed electrical models representing the metal/solution interface. The fitting of the data can verify or role out mechanistic models and enables the calculation of numerical values corresponding to physical and/or chemical properties of the system under investigation ${ }^{24,25}$. Figure 2 shows the Nyquist plot for tin in $0.6 \mathrm{M} \mathrm{NaCl}$ in the absence and presence of different concentrations of 
compound (S11) at $25{ }^{\circ} \mathrm{C}$. This diagram has a semicircle appearance; it indicates that the corrosion of tin is mainly controlled by a charge transfer process. The high frequency limit corresponds to electrolyte resistance $\mathrm{R}_{\Omega}$, while the low frequency limit represents the sum of $\left(R_{\Omega}+R_{p}\right)$ where $R_{p}$ is the first approximation determined by both the electrolytic conductance of the oxide film and polarization resistance of the dissolution and passivation process. The experimental impedance values were fitted to a simple equivalent circuit model consisting of a parallel combination representing the electrode capacitance, $\mathrm{C}_{\mathrm{dl}}$ and the corrosion resistance, $\mathrm{R}_{\mathrm{ct}}$, in series with a resistor, $\mathrm{R}_{\mathrm{S}}$, representing the ohmic drop in the electrolyte. The equivalent circuit parameters were calculated and presented in Table 3.

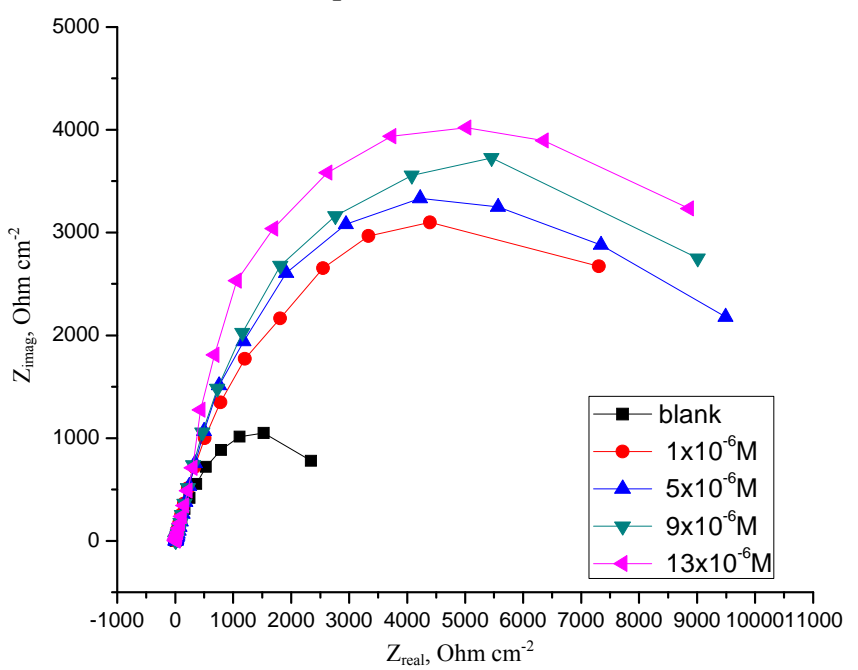

Figure 2. The Nyquist plot for tin in $0.6 \mathrm{M} \mathrm{NaCl}$ solution in the absence and presence of different concentration of $\mathrm{S} 11$ at $25{ }^{\circ} \mathrm{C}$

Table 3. Electrochemical kinetic parameters obtained from EIS technique for the corrosion of tin in $0.6 \mathrm{M} \mathrm{NaCl}$ at different concentrations of investigated compounds at $25^{\circ} \mathrm{C}$

\begin{tabular}{cccccc}
\hline Compounds & Conc. $\times 10^{6} \mathrm{M}$ & $\mathrm{R}_{\mathrm{ct}}, \Omega \mathrm{cm}^{2}$ & $\mathrm{C}_{\mathrm{dl}}, \mu \mathrm{F} \mathrm{cm}$ & $\Theta$ & $\% \mathrm{IE}$ \\
\hline blank & 0.0 & 2.271 & 8.522 & - & - \\
& 1 & 10.90 & 5.629 & 0.972 & 97.2 \\
S11 & 5 & 12.94 & 4.756 & 0.824 & 82.4 \\
& 9 & 13.91 & 4.227 & 0.837 & 83.7 \\
& 13 & 14.16 & 3.759 & 0.840 & 84.0 \\
& 1 & 9.881 & 4.968 & 0.770 & 77.0 \\
$\mathrm{~S} 12$ & 5 & 10.25 & 4.692 & 0.778 & 77.8 \\
& 9 & 12.68 & 3.871 & 0.828 & 82.8 \\
& 13 & 12.77 & 3.311 & 0.822 & 82.2 \\
$\mathrm{~S} 13$ & 1 & 8.781 & 4.303 & 0.741 & 74.1 \\
& 5 & 9.843 & 3.602 & 0.769 & 76.9 \\
& 9 & 10.60 & 3.165 & 0.786 & 78.6 \\
$\mathrm{~S} 14$ & 13 & 12.33 & 2.120 & 0.816 & 81.6 \\
& 1 & 8.651 & 2.875 & 0.737 & 73.7 \\
& 5 & 8.844 & 2.078 & 0.743 & 74.3 \\
& 9 & 9.614 & 1.265 & 0.764 & 76.4 \\
& 13 & 12.00 & 0.056 & 0.811 & 81.1 \\
\hline
\end{tabular}




\section{Electrochemical frequency modulation (EFM) measurements}

The EFM is a nondestructive corrosion measurement technique that can directly give values of the corrosion current without prior knowledge of Tafel constants. Like EIS, it is a small signal ac technique. Unlike EIS, however, two sine waves (at different frequencies) are applied to the cell simultaneously. Intermodulation spectra obtained from EFM measurements in absence and presence of compound (S11) is presented in Figures $3 \mathrm{a} \& 3 \mathrm{~b}$ as an example of tin in $0.6 \mathrm{M}$ $\mathrm{NaCl}$ and in presence of $13 \times 10^{-6} \mathrm{M} \mathrm{S} 11$ at $25{ }^{\circ} \mathrm{C}$ respectively. Each spectrum is a current response as a function of frequency. The two large peaks are the response to the $2 \mathrm{~Hz}$ and $5 \mathrm{~Hz}$ excitation frequencies. These peaks are used by the EFM 140 software package to calculate the corrosion current and Tafel constants.

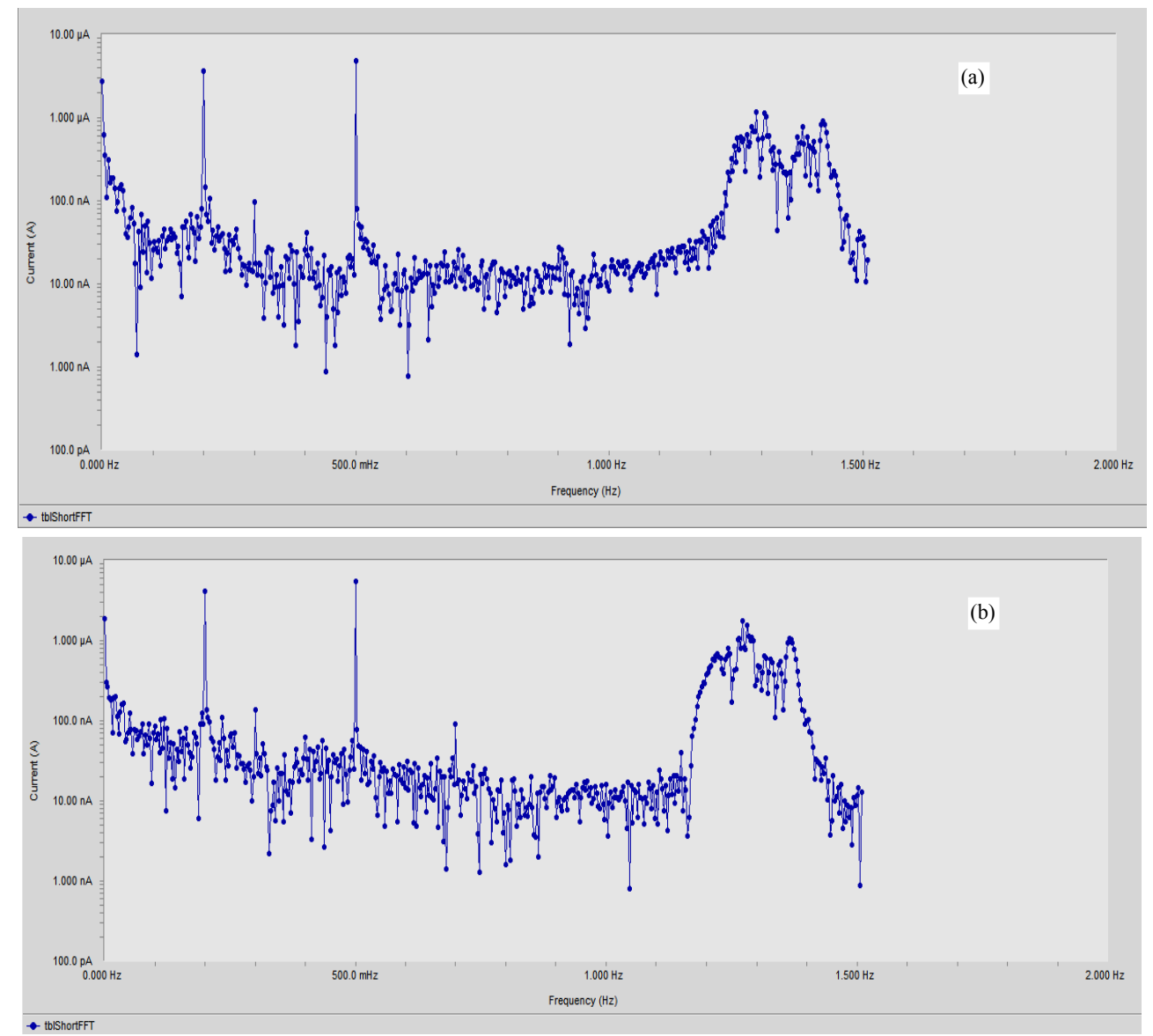

Figure 3. (a) EFM charts for tin in $0.6 \mathrm{M} \mathrm{NaCl}$ solution at $25^{\circ} \mathrm{C}$; (b) $\mathrm{EFM}$ charts for tin in $0.6 \mathrm{M} \mathrm{NaCl}$ solution and presence of $13 \times 10^{-6} \mathrm{M}$ of compound $\mathrm{S} 11$ at $25^{\circ} \mathrm{C}$

The calculated corrosion kinetic parameters at different concentrations of the investigated extract in $0.6 \mathrm{M} \mathrm{NaCl}$ at $25^{\circ} \mathrm{C}\left(\mathrm{i}_{\text {corr }}, \beta_{\mathrm{a}}, \beta_{\mathrm{c}}, \mathrm{CF}-2, \mathrm{CF}-3\right.$ and $\left.\% \mathrm{IE}\right)$ are given in Table 4. From it, the corrosion current densities decrease by increasing the concentration of inhibitors and hence, inhibition efficiency increases. The causality factors in Table 4 are very close to theoretical values which according to EFM theory should guarantee the validity of Tafel slopes and corrosion current densities. Values of causality factors in Table 4 indicate 
that the measured data are of good quality ${ }^{26}$. The standard values for CF-2 and CF-3 are 2.0 and 3.0, respectively. The deviation of causality factors from their ideal values might due to the perturbation amplitude was too small or the resolution of the frequency spectrum is not high enough also another possible explanation that the inhibitor is not performing very well. It can be seen that the inhibition efficiency is in the order: S11 $>$ S12 $>$ S13 $>$ S14.

Table 4. Data from electrochemical frequency modulation of tin in $0.6 \mathrm{M} \mathrm{NaCl}$ containing different concentrations of compound (S11) at $25^{\circ} \mathrm{C}$

\begin{tabular}{|c|c|c|c|c|c|c|c|c|c|}
\hline Compd. & $\begin{array}{c}\text { Conc. }, \mathrm{X} \\
10^{6} \mathrm{M}\end{array}$ & $\begin{array}{c}\mathrm{i}_{\text {corr }} \\
\mu \mathrm{A} \mathrm{cm}^{-2}\end{array}$ & $\begin{array}{c}\beta_{\mathrm{a}}, \\
\mathrm{mV} \mathrm{dec}^{-1}\end{array}$ & $\begin{array}{c}\beta_{\mathrm{c}} \\
\mathrm{mV} \mathrm{dec}^{-1}\end{array}$ & $\mathrm{CF}-2$ & CF-3 & $\begin{array}{l}\text { C.R. } \\
\text { mpy }\end{array}$ & $\Theta$ & $\begin{array}{l}\% \\
\text { IE }\end{array}$ \\
\hline \multirow[t]{2}{*}{ blank } & 0.0 & 20.73 & 155 & 166 & 2.395 & 2.345 & 20.27 & - & - \\
\hline & 1 & 11.38 & 147 & 185 & 2.945 & 3.953 & 11.12 & 0.451 & 45.1 \\
\hline \multirow{5}{*}{ S11 } & 5 & 9.227 & 133 & 148 & 1.279 & 3.294 & 9.019 & 0.555 & 55.5 \\
\hline & 9 & 7.451 & 89 & 101 & 2.090 & 3.853 & 7.283 & 0.641 & 64.1 \\
\hline & 13 & 5.438 & 70 & 78 & 2.892 & 3.765 & 5.316 & 0.738 & 73.8 \\
\hline & 1 & 11.89 & 114 & 124 & 2.318 & 3.407 & 11.62 & 0.426 & 42.6 \\
\hline & 5 & 9.906 & 163 & 244 & 2.738 & 3.470 & 9.684 & 0.522 & 52.2 \\
\hline \multirow[t]{3}{*}{$\mathrm{S} 12$} & 9 & 7.618 & 104 & 116 & 2.118 & 3.787 & 7.447 & 0.633 & 63.3 \\
\hline & 13 & 5.704 & 114 & 192 & 2.585 & 3.896 & 5.575 & 0.725 & 72.5 \\
\hline & 1 & 12.34 & 123 & 132 & 2.034 & 2.94 & 12.06 & 0.405 & 40.5 \\
\hline \multirow{3}{*}{ S13 } & 5 & 10.34 & 149 & 196 & 2.431 & 3.350 & 10.11 & 0.501 & 50.1 \\
\hline & 9 & 8.530 & 101 & 109 & 2.696 & 3.220 & 8.34 & 0.589 & 58.9 \\
\hline & 13 & 6.386 & 137 & 196 & 2.346 & 2.933 & 6.243 & 0.692 & 69.2 \\
\hline \multirow{4}{*}{ S14 } & 1 & 13.11 & 121 & 126 & 3.437 & 6.304 & 12.81 & 0.368 & 36.8 \\
\hline & 5 & 11.32 & 179 & 249 & 2.553 & 3.123 & 11.06 & 0.454 & 45.4 \\
\hline & 9 & 8.734 & 122 & 208 & 2.382 & 2.723 & 8.538 & 0.579 & 57.9 \\
\hline & 13 & 7.045 & 82 & 87 & 2.742 & 3.472 & 6.887 & 0.6602 & 66.0 \\
\hline
\end{tabular}

Adsorption isotherm

The investigated compounds inhibit the corrosion by adsorption at the metal surface. Theoretically, the adsorption process has been regarded as a simple substitutional process, in which an organic molecule in the aqueous phase substitutes an y number of water molecules adsorbed on the metal surface ${ }^{23}$. Theoretically, the adsorption process can be regarded as a single substitutional process in which an inhibitor molecule, $\mathrm{L}_{\text {inh }}$, in the aqueous phase substitutes an " $x$ " number of water molecules adsorbed on the metal surface ${ }^{27}$.

$$
\mathrm{L}_{\text {inh (aq) }}+\mathrm{xH}_{2} \mathrm{O}_{\text {(sur) }} \rightarrow \mathrm{L}_{\text {inh (sur) }}+\mathrm{xH}_{2} \mathrm{O}_{\text {(aq) }}
$$

Where $\mathrm{x}$ is known as the size ratio and simply equals the number of adsorbed water molecules replaced by a single inhibitor molecule. The adsorption depends on the structure of the inhibitor, the type of the metal and the nature of its surface, the nature of the corrosion medium and its $\mathrm{pH}$ value, the temperature and the electrochemical potential of the metalsolution interface. Also, the adsorption provides information about the interaction among the adsorbed molecules themselves as well as their interaction with the metal surface. It is essential to know the mode of adsorption and the adsorption isotherm that fits the experimental results. Many attempts have been made to fit the surface coverage data to different adsorption isotherms. The adsorption of these investigated compounds on the tin surface was found to obey the Freundlich adsorption isotherm (Figure 4), according to:

$$
\Theta=K_{\text {ads }} C^{n}
$$


Where $\mathrm{C}$ is the equilibrium concentration of the investigated compounds, $\mathrm{n}$ is a constant depending on the characteristics of the adsorbed molecule, where $0<\mathrm{n}<1, \mathrm{~K}_{\mathrm{ads}}$ is the equilibrium constant for adsorption/desorption process and $\theta$ is the fraction of the surface coverage $^{28} . \mathrm{K}_{\mathrm{ads}}$ is related to the free energy of adsorption, $\Delta \mathrm{G}^{\mathrm{o}}$ ads, according to:

$$
\mathrm{K}_{\mathrm{ads}}=1 / \mathrm{C}_{\text {solvent }} \exp \left(-\Delta \mathrm{G}^{\mathrm{o}}{ }_{\mathrm{ads}} / \mathrm{RT}\right)
$$

Where $\mathrm{C}_{\text {solvent is }}$ the molar concentration of the solvent, which is $55.5 \mathrm{M}^{-1}$ for aqueous solutions. This linear relation can be used for the calculation of the values of both $\mathrm{K}_{\mathrm{ads}}$ and $\mathrm{n}$ for the investigated inhibitors.

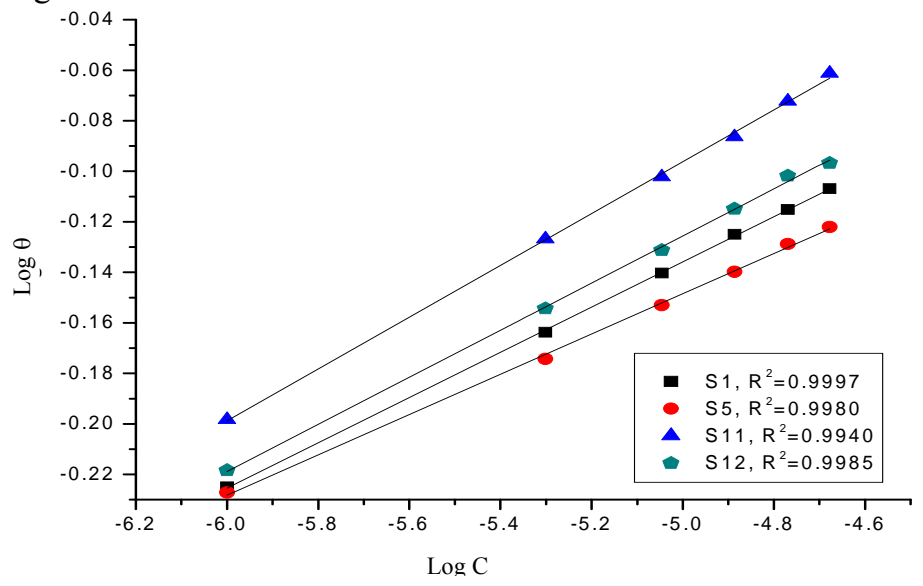

Figure 4. Curve fitting of corrosion data for tin alloy in $0.6 \mathrm{M} \mathrm{NaCl}$ in presence of different concentrations of inhibitors corresponding to Freundlich adsorption isotherm at $25{ }^{\circ} \mathrm{C}$

Also it is found that the kinetic thermodynamic model of El-Awady et al., ${ }^{29}$ is fit well to the experimental data of tin in the presence of varying concentrations of tested compounds in $0.6 \mathrm{M} \mathrm{NaCl}$. The adsorption isotherm relationship is represented by the following equation:

$$
\log (\Theta / 1-\Theta)=\log K^{\prime}+y \log C
$$

Where $\mathrm{y}$ is the number of inhibitor molecules occupying one active site, $\mathrm{K}=\mathrm{K}^{(1 / \mathrm{y})}$ and $1 / \mathrm{y}$ is the number of adsorbed water molecules replaced by one molecules of organic inhibitor.

Application of kinetic-thermodynamic equation yields a straight line with slope of $y$ and intercept of $\log \mathrm{K}^{\prime}$ illustrated in Figure 5. The results in Table 5 show the values of $\Delta \mathrm{G}_{\text {ads, }}^{\circ} \mathrm{K}_{\mathrm{ads}}$ and 1/y obtained from El-Awady et al. and Freundlich adsorption isotherm. Inspection of Table 5 shows that the number of active sites is nearly constant and approximately equals one, this behavior can be discussed on the basis that the adsorption process takes place by the occupation of one active site per single inhibitor molecules. Also, the equilibrium constant $\left(\mathrm{K}_{\mathrm{ads}}\right)$ decreases in the order: $\mathrm{S} 11>\mathrm{S} 12>\mathrm{S} 14>\mathrm{S} 15$. Large values of $\mathrm{K}_{\mathrm{ads}}$ mean better inhibition efficiency of a given inhibitors, i.e., strong electric interaction between the double layer existing at the phase boundary and the adsorbing molecules. The values of $\Delta \mathrm{G}_{\text {ads }}^{\circ}$ are large and acquire negative sign indicating that the adsorption reaction is proceeding spontaneously and accompanied with a high efficient adsorption for such compounds.

According to Freundlich model, the data Table 5 indicate that the value of $\left(\mathrm{K}_{\mathrm{ads}}\right)$ decreases in the order: $\mathrm{S} 11>\mathrm{S} 12>\mathrm{S} 13>\mathrm{S} 14$. It is seen that there is a good agreement between the values of $\left(\mathrm{K}_{\mathrm{ads}}\right)$ and $\left(\Delta \mathrm{G}_{\mathrm{ads}}^{\circ}\right)$ obtained from the kinetic model and Freundlich model isotherm. 


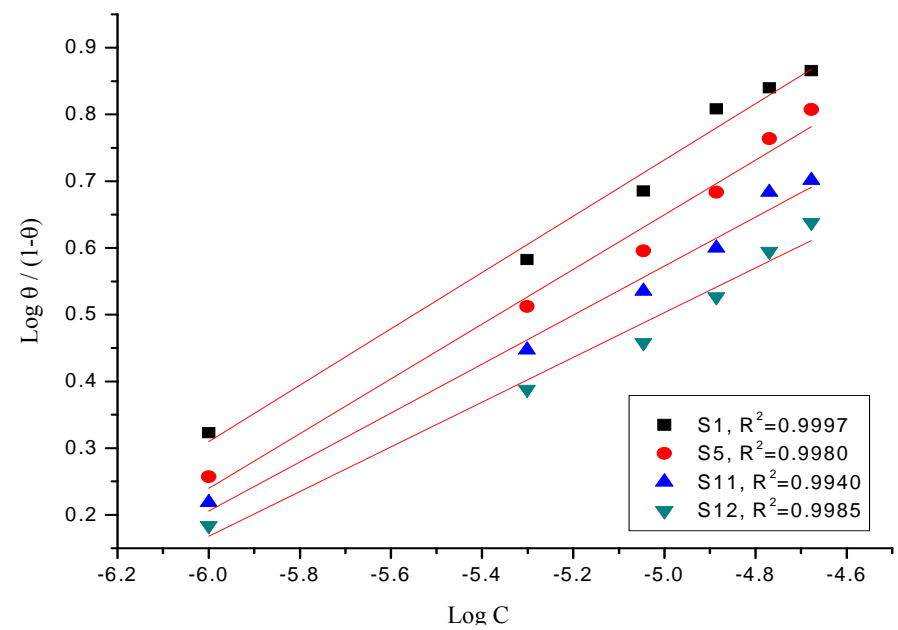

Figure 5. Curve fitting of corrosion data for tin in $0.6 \mathrm{M} \mathrm{NaCl}$ in presence of different concentrations of inhibitors corresponding to kinetic model at $25{ }^{\circ} \mathrm{C}$

Table 5. Equilibrium constant $\left(\mathrm{K}_{\mathrm{ads}}\right)$ and free energy of adsorption $\left(\Delta \mathrm{G}_{\mathrm{ads}}^{\mathrm{o}}\right)$ in the presence of $11 \times 10^{-6} \mathrm{M}$ different inhibitors at $25^{\circ} \mathrm{C}$

\begin{tabular}{ccccc}
\hline \multirow{2}{*}{ Inhibitors } & \multicolumn{2}{c}{ Kinetic model } & \multicolumn{2}{c}{ Freundlich } \\
\cline { 2 - 5 } & $\mathrm{K}_{\mathrm{ads}} \times 10^{-7} \mathrm{M}^{-1}$ & $-\Delta \mathrm{G}_{\text {ads }}^{\mathrm{o}} \mathrm{kJ} \mathrm{mol}^{-1}$ & $\mathrm{~K}_{\mathrm{ads}} \times 10^{-6} \mathrm{M}^{-1}$ & $-\Delta \mathrm{G}_{\text {ads }}^{\mathrm{o}} \mathrm{kJ} \mathrm{mol}^{-1}$ \\
\hline S11 & 30.1 & 58.3 & 8.1 & 49.4 \\
$\mathrm{~S} 12$ & 8.1 & 55.1 & 3.8 & 47.5 \\
$\mathrm{~S} 13$ & 6.9 & 54.7 & 2.3 & 46.3 \\
$\mathrm{~S} 14$ & 2.8 & 52.5 & 1.3 & 44.85 \\
\hline
\end{tabular}

Effect of temperature

In order to gain more information about the type of adsorption and the effectiveness of the studied inhibitors at higher temperatures, polarization was performed at different temperatures $\left(30-50{ }^{\circ} \mathrm{C}\right.$ ) for tin in $0.6 \mathrm{M}$ solution of $\mathrm{NaCl}$ without and with selected concentrations of the studied inhibitors. The data indicate that the inhibition efficiency slightly decreases with increasing temperature for all investigated inhibitors.

A plot of $\left(\log \mathrm{j}_{\text {corr }} v s .1 / \mathrm{T}\right)$ gives straight lines with slope $\mathrm{E}_{\mathrm{a}} / 2.303 \mathrm{R}$. The intercept be A. Figure 6 represents the relation between $\log$ (rate) and reciprocal of the absolute temperature of tin in $0.6 \mathrm{M}$ solution of $\mathrm{NaCl}$ in the presence and absence of investigated compounds. The values of $\mathrm{E}_{\mathrm{a}}^{*}$ are given in Table 6 . Data of this Table reveal high activation energies for the inhibition process by different compounds, indicating their higher protective efficiency ${ }^{30}$. An experimental dependence of Arrhenius-type equation on temperature is observed between the corrosion rate and temperature.

$$
\mathrm{i}_{\text {corr }}=\mathrm{A} \exp \left(-\mathrm{E}_{\mathrm{a}} / \mathrm{RT}\right)
$$

Where $i_{\text {corr }}$ is the corrosion current density, $A$ is the extrapolation factor, $E_{a}$ is the activation energy, $\mathrm{R}$ is the gas constant and $\mathrm{T}$ is the absolute temperature. It is clear that the activation energy increases with increasing the efficiency of the investigated compounds in the following order: $\mathrm{S} 11>\mathrm{S} 12>\mathrm{S} 13>\mathrm{S} 14$. Such behavior is attributed to the formation of energy barrier, due to the adsorption of the inhibitors on the alloy surface forming a film. This is another pointer to inhibitor physisorption. 


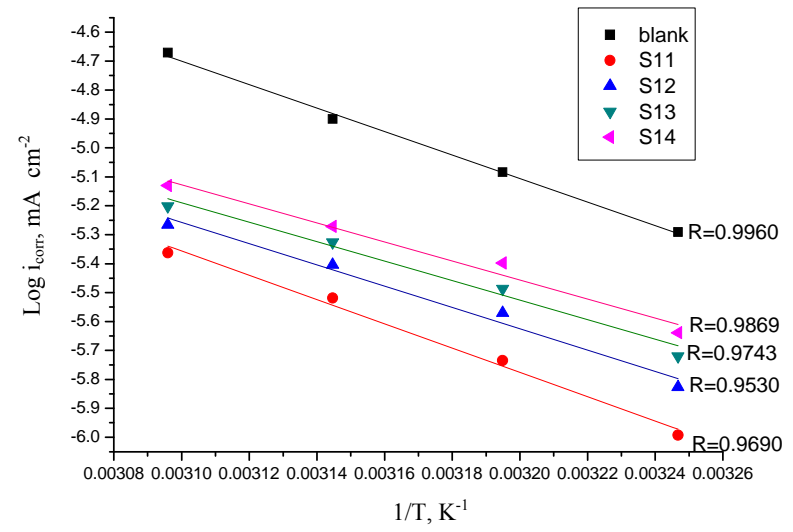

Figure 6. Arrhenius plots ( $\log \mathrm{i}_{\text {corr }} v s .1 / \mathrm{T}$ curves) for tin dissolution in $0.6 \mathrm{M} \mathrm{NaCl}$ in the absence and presence of $21 \times 10^{-6} \mathrm{M}$ different inhibitors at different temperatures

Table 6. Effect of different temperatures on thermodynamic activation parameters; the activation energy $\left(E_{a}^{*}\right)$, activation, enthalpy $\left(\Delta H^{*}\right)$ and activation entropy $\left(\Delta S^{*}\right)$ of tin corrosion in $0.6 \mathrm{M} \mathrm{NaCl}$ in the absence and presence of $21 . \times 10^{-6} \mathrm{M}$ different inhibitors

\begin{tabular}{cccc}
\hline Inhibitor & $-\mathrm{E}_{\mathrm{a}}^{*}, \mathrm{~kJ} \mathrm{~mol}^{-1}$ & $\Delta \mathrm{H}^{*}, \mathrm{~kJ} \mathrm{~mol}^{-1}$ & $-\Delta \mathrm{S}^{*}, \mathrm{~J} \mathrm{~mol}^{-1} \mathrm{~K}^{-1}$ \\
\hline blank & 70.7 & 148 & 39.8 \\
S11 & 78.3 & 157 & 39.8 \\
S12 & 76.5 & 143 & 29.7 \\
S13 & 74.5 & 135 & 32.3 \\
S14 & 72.9 & 131 & 36.1 \\
\hline
\end{tabular}

An alternative formulation of Arrhenius equation is the transition state equation ${ }^{31}$.

$$
\mathrm{i}_{\text {corr }}=\mathrm{RT} / \mathrm{Nh} \exp \left(\Delta \mathrm{S}^{*} / \mathrm{R}\right) \exp \left(-\Delta \mathrm{H}^{*} / \mathrm{RT}\right)
$$

Where $\mathrm{h}$ is the Planck's constant, $\mathrm{N}$ is Avogadro number, $\Delta \mathrm{S}^{*}$ is the entropy change of activation and $\Delta \mathrm{H}^{*}$ is the enthalpy change of activation. Figure 7 shows a plot of $\log \left(\mathrm{i}_{\text {corr }} / \mathrm{T}\right)$ against $(1 / \mathrm{T})$ straight line are obtained with a slope of $\left(-\Delta \mathrm{H}^{*} / 2.303 \mathrm{R}\right)$ and intercept of $(\log \mathrm{R} / \mathrm{Nh}$ $\left.+\Delta \mathrm{S}^{*} / 2.303 \mathrm{R}\right)$ from which the value of $\Delta \mathrm{H}^{*} \& \Delta \mathrm{S}^{*}$ are calculated and are given in Table 5.

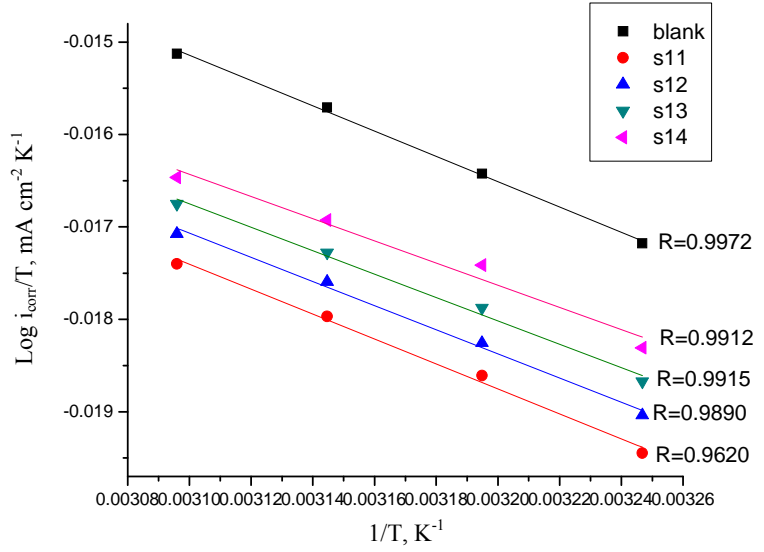

Figure 7. $\log \mathrm{i}_{\text {corr }} / \mathrm{T}-1 / \mathrm{T}$ curves for tin dissolution in $0.6 \mathrm{M} \mathrm{NaCl}$ in the absence and presence of $21 \times 10^{-6} \mathrm{M}$ different inhibitors at different temperatures 
From Table 5 it is clear that the positive value of $\Delta \mathrm{H}^{*}$ reflects the endothermic nature of dissolution process. The Table also, shows that the presence of the inhibitor produces higher values for $\Delta \mathrm{H}^{*}$ than those obtained for the uninhibited solution. This indicates higher protection efficiency. This may be attributed to the presence of an energy barrier for the reaction, that is, the process of adsorption leads to a rise in enthalpy of the corrosion process. In addition, the values of $\Delta \mathrm{S}^{*}$ are large and negative. This implies that the activated complex in the rate determining step represents association rather than dissociation meaning that a decrease in disordering takes place on going from reactants to activated complex and the increase in the system ordering ${ }^{32,33}$.

\section{Theoretical studies}

To investigate the effect of ring structure on the inhibition mechanism and efficiency some quantum chemical calculations were performed. Geometric and electronic structures of the inhibitors were calculated by optimization of their bond angles and bond lengths. The optimized molecular structures of the inhibitors are given in Figure 8. Highest occupied molecular orbital $\mathrm{E}_{\text {Hомо }}$ and lowest unoccupied molecular orbital $\mathrm{E}_{\mathrm{LUMO}}$ energies, $\mathrm{E}_{\mathrm{LUMO}^{-}}$ $\mathrm{E}_{\text {Hомо }}$ energy gap $(\Delta \mathrm{E})$ and dipole moment, $\mu$, are given in Table 7.

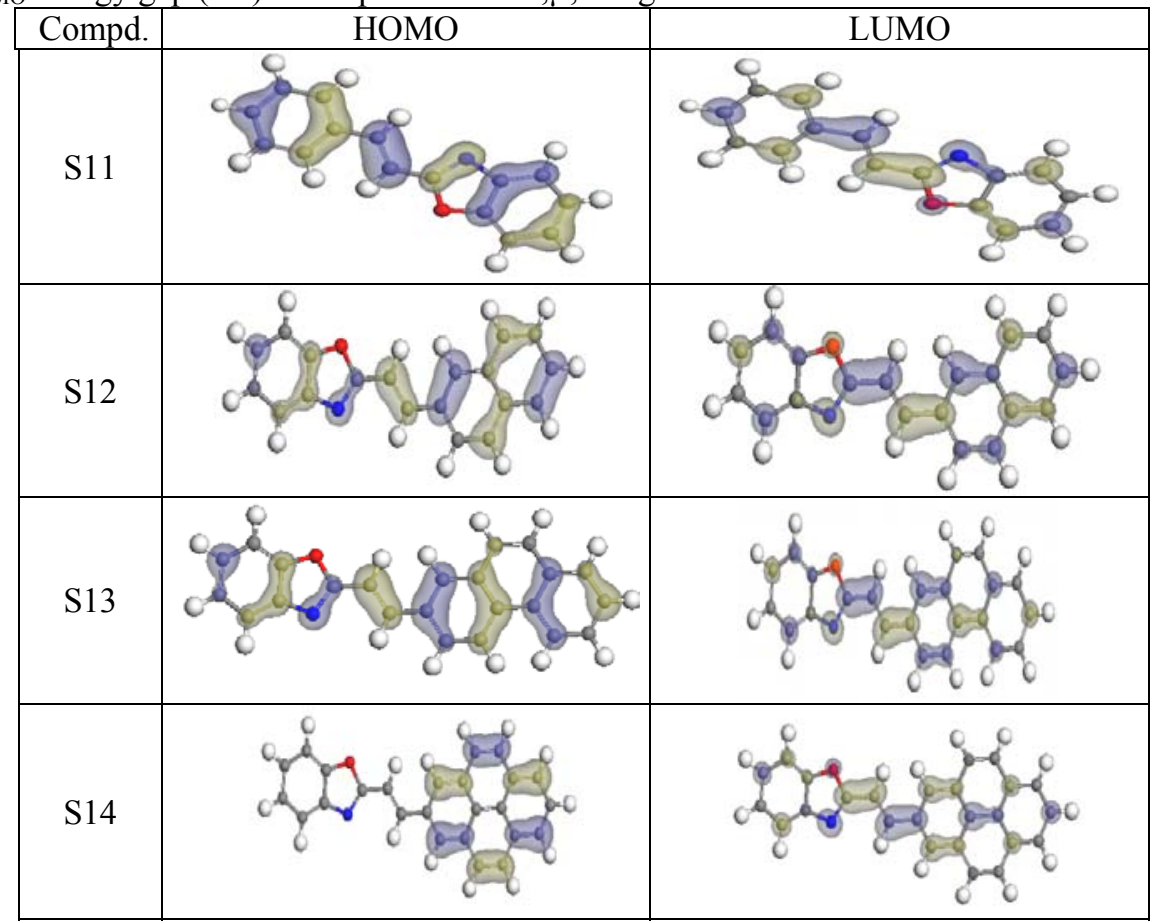

Figure 8. Optimized HOMO and LUMO structures of some propaneitrile derivatives

Table 7. Quantum chemical parameter for investigated propanenitrile derivatives

\begin{tabular}{ccccc}
\hline Parameter & S14 & S13 & S12 & S11 \\
\hline$-\mathrm{E}_{\text {HOMO }}(\mathrm{eV})$ & 9.157 & 8.960 & 8.900 & 8.600 \\
$-\mathrm{E}_{\text {LUMO }}(\mathrm{eV})$ & 1.298 & 1.433 & 1.406 & 1.400 \\
$\Delta \mathrm{E}(\mathrm{eV})$ & 7.859 & 7.537 & 7.494 & 7.200 \\
$\mu$ (debyes) & 2.004 & 2.040 & 2.070 & 2.285 \\
\hline
\end{tabular}


$\mathrm{E}_{\mathrm{HOMO}}$ often is associated with the electron donating ability of the molecule. High values of $\mathrm{E}_{\text {номо }}$ are likely to indicate a tendency of the molecule to donate electrons to appropriate acceptor molecules with low energy, empty molecular orbitals. Therefore, the energy of the lowest unoccupied molecular orbitals indicates the ability of the molecule to accept electrons. The lower the value of $\mathrm{E}_{\mathrm{LUMO}}$, the most probable it is that the molecule accepts electron ${ }^{34}$. The percent inhibition efficiencies increase if the molecules have higher or less negative HOMO energies. The highest values of the HOMO density were found in the vicinity of sulphur and nitrogen atoms, clearly indicating the nucleophilic center is the sulphur and nitrogen atoms Figure (8). Table (7) shows the calculated values of dipole moment, $\mu$, of the studied molecules. Highest dipole moment values were observed with compound S11. Other authors state that the inhibition efficiency increases with increasing value of the dipole moment ${ }^{35}$ but on the other hand, a survey of literature reveals that irregularities appeared in the case of correlation of dipole moment with efficiency ${ }^{36}$. Also, from this Table the value of $\Delta \mathrm{E}$ decreased when increasing the inhibition efficiency indicating that the more of inhibitors, the stronger interaction between inhibitors and metal surface. Thus, the interactions are probably physical adsorption, and the interactions between the inhibitors and the metal surface might be ascribed to the hyper conjugation interactions- $\pi$ stacking $^{37}$. As gathered from the higher values of $\mathrm{E}_{\mathrm{HOMO}}$, dipole moment and the lower values of $\mathrm{E}_{\mathrm{LUMO}}$ the order on inhibition efficiency is as follows: S11 > S $12>\mathrm{S} 13>\mathrm{S} 14$.

\section{Conclusion}

We studied the inhibitor action of investigated propanenitrile derivatives on corrosion of tin in $0.6 \mathrm{M} \mathrm{NaCl}$ depending on effect of temperature. We obtained the following conclusions:

(1) Based on the Tafel polarization results, the \% IE of investigated propaneitrile derivatives is found to decrease with increasing temperature, and its addition to $1 \mathrm{M} \mathrm{HCl}$ leads to an increase of apparent activation energy $\left(\mathrm{E}_{\mathrm{a}}^{*}\right)$ of the corrosion process.

(2) The corrosion process is inhibited by the adsorption of propanenitriles derivatives on tin surface. This adsorption fits a Freundlich isotherm model. Thermodynamic adsorption parameters show that propanenitriles derivatives are adsorbed on tin surface by an exothermic and spontaneous process.

(3) The calculated values of $\Delta \mathrm{G}_{\text {ads }}^{\mathrm{a}}$ corroborate that the adsorption mechanism of propanenitriles derivatives on tin surface in $0.6 \mathrm{M} \mathrm{NaCl}$ solution is mainly due to physisorption.

(4) At temperatures higher than $30{ }^{\circ} \mathrm{C}$, these inhibitors are not efficient to control the corrosion of tin in $0.6 \mathrm{M} \mathrm{NaCl}$ at the concentration range studied.

\section{References}

1. Mohran H S, El-Sayed A and Abd El-Lateef H M, J Solid State Electrochem., 2009, 13(8), 1279-1290; DOI:10.1007/s10008-008-0676-2

2. S. Kapusta, N. Hackerman, Electrochim Acta, 1980, 25(12), 1625-1639;

DOI:10.1016/0013-4686(80)80016-8

3. Foad El Sherbini E, Mat Chem Phys., 1999, 60(3), 286-290; DOI:10.1016/S02540584(99)00093-0

4. Migahed M A, Azzam E M S and Al-Sabagh A M, Mater Chem Phys., 2004, 85(2-3), 273-279; DOI:10.1016/j.matchemphys.2003.12.027

5. Kunze E, Korrosion und Korrosionschutz, Wiley-VCH, Weinheim, 2001, 6. 
6. $\quad$ Eddy N O, Ibok U J and Ebenso E E, J Appl Electrochem., 2010, 40, 445-456.

7. Seruga M, Melikos-Hukovic M, Valla T, Milun M, Hosch- ultz H and Wandelt K, $J$ Electroanal Chem., 1996, 407, 83-89

8. Ajmal M, Mideen A S and Quaraishi M A, Corros Sci., 1994, 36(1), 79-84; DOI:10.1016/0010-938X(94)90110-4

9. El-Etre A Y and Abdallah M, Corros Sci., 2000, 42, 731-738; DOI:10.1016/S0010938X(99)00106-7

10. Abdallah M, Corros Sci., 2002, 44(4), 717-728; DOI:10.1016/S0010938X(01)00100-7

11. Hosseini S M A and Azimi A, Corros Sci., 2009, 51(4), 728-732;

DOI:10.1016/j.corsci.2008.11.019

12. Bockris $\mathrm{J} \mathrm{O} \mathrm{M}$ and Reddy A K N, Modern Electrochemistry 2B, Electrodics in chemistry, engineering, biology and environmental science, $2^{\text {nd }}$ Ed., Kluwer Academic/Plenum Publishers, New York, 2000, 1703.

13. Ashassi-Sorkhabi H and Asghari E, Electrochim Acta, 2008, 54(2), 162-167; DOI:10.1016/j.electacta.2008.08.024

14. Ali S A and Saeed M T, Polymers, 2001, 42(7), 2785-2794; DOI:10.1016/S00323861(00)00665-0

15. Ebenso E E, Ekpe U J, Ita B I, Offiong O E and Ibok U J, Mater Chem Phys., 1999, 60(1), 79-90; DOI:10.1016/S0254-0584(99)00074-7

16. Quraishi M A, Khan M A W, Ajmal M, Muralidharan S and Iyer S V, Anti Corros Meth Mater., 1996, 43, 5-12

17. Khaled K F, Babic-Samardzija K and Hackerman N, J Appl Electrochem., 2004, 34(7), 697-704; DOI:10.1023/B:JACH.0000031160.88906.03

18. Rodriguez-Valdez L M, Martinez-Villafane A and Glossman-Matnik D, J Mol Struct THEOCHEM., 2005, 713(1-3), 65-70; DOI:10.1016/j.theochem.2004.10.036

19. Arun Y, Bhaskar G, Balachandran C, Ignacimuthu S and Perumal P T, Bioorg Med Chem Lett., 2013, 23, 1839-1845; (b) Radwan M A A, Ragab E A, Sabry N M and ElShenawy S M, Bioorg Med Chem., 2007, 15, 3832-3841; (c) Sheehan J C, Mania D, Nakamura S, Stock J A and Maeda K, J Am Chem Soc., 1968, 90, 462-470.

20. Vracar L J and Drazie D M, Corros Sci., 2002, 44(8), 1669-1680; DOI:10.1016/S0010-938X(01)00166-4

21. Li W, He Q, Zhang S, Pei C and Hou B, J Appl Electrochem., 2008, 38(3), 289-295; DOI:10.1007/s10800-007-9437-7

22. De Souza S F, Corros Sci., 2009, 51(3), 642-649; DOI:10.1016/j.corsci.2008.12.013

23. Macdonald J R, Annals Biomedical Engineering, 1992, 20(3), 289-305; DOI:10.1007/BF02368532

24. Badawy W A, Ismaila K M, Fathi A M, Electrochim Acta, 2005, 50(18), 3603-3608; DOI:10.1016/j.electacta.2004.12.030

25. Badawy W A, El-Egamy S S and Ismail K M, Int J Electrochem Sci., 2011, 6, 6469-6482

26. Abd El-Rehim S S, Refaey S A M, Taha F, Saleh M B and Ahmed R A, J Appl Electrochem.. 2001, 31(4), 429-435; DOI:10.1023/A:1017592322277

27. Pardo A, Merino M C, Carboneras M, Viejo F, Arrabal R and Muñoz J, Corros Sci., 2006, 48(5), 1075-1085; DOI:10.1016/j.corsci.2005.05.002

28. Atkin P W, Physical Chemistry, $5^{\text {th }}$ Ed., Oxford University Press. Oxford, 1994, 877

29. Harek Y and Larabi L, Corrosion Inhibition of Mild Steel, Kem Ind., 2004, 53, 55-61.

30. Abd El-Rehim S S, Hamdy H H and Amin M A, Corros Sci., 2004, 46(1), 5-25; DOI:10.1016/S0010-938X(03)00133-1 
31. Al-Juaid S S, Port Electrochim Acta, 2007, 25(3), 363-373

32. Umoren S A, Obot I B, Ebenso E E and Obi-Egbedi N O, Desalination, 2009, 247(1-3), 561-572; DOI:10.1016/j.desal.2008.09.005

33. El-Etre A Y, Corros Sci., 2003, 45(11), 2485-2495; DOI:10.1016/S0010938X(03)00066-0

34. Lukovits I, Palfi K and Kalman E, Corrosion, 1997, 53, 915-919.

35. Popova A. Christov M, Raicheva S and Sokolova E, Corros Sci., 2004, 46(6), 1333130; DOI:10.1016/j.corsci.2003.09.025

36. Kaled K F, Babic-Samardzij K and Hackerman N, J Appl Electrochem., 2004, 34, 697-704

37. Alvarez P M, Garacia-Araya J F, Beltran F J, Masa F J and Medina F, $J$ Collod Interface Sci., 2005, 283(2), 503-512; DOI:10.1016/j.jcis.2004.09.014 